\title{
Editorial
}

\section{Anabolic-Androgenic Steroid Use and Body Image in Men: A Growing Concern for Clinicians}

\author{
Gen Kanayama $^{a, b}$ James I. Hudson ${ }^{a, b}$ Harrison G. Pope, Jr. ${ }^{\text {a, b }}$ \\ ${ }^{a}$ Biological Psychiatry Laboratory, McLean Hospital, Belmont, MA, USA; ${ }^{b}$ Harvard Medical School, Boston, MA, USA
}

Recent decades have seen increasing attention to disorders of body image [1]. In the past, most body-image studies have focused on women [2], and especially women with eating disorders [3], but now a growing literature has also begun to address body image disorders in men [4]. In particular, it appears that today's men have become increasingly preoccupied with having a lean and muscular body, perhaps as a result of constant exposure to lean and muscular male images in movies, television, advertising, and elsewhere $[1,5]$. Modern mental health professionals are very likely to encounter male patients who harbor such concerns. Importantly, many of these men use drugs (or "dietary supplements" containing drugs) in order to gain muscle or lose body fat. The use of these "body image drugs" had already surfaced as a clinical issue 20 years ago [6] and has generated increasing attention in recent years [7]. From a public health standpoint, the most concerning of these substances are the anabolic-androgenic steroids (AAS) - the family of hormones that includes testosterone and its synthetic derivatives. In this paper, we present a clinical update on AAS use.

Drugs in the AAS family all possess both anabolic (muscle-building) properties and androgenic (masculinizing) properties [8]. Soon after the identification of testosterone in the late 1930s, athletes discovered that AAS could allow them to greatly increase muscle mass, and

\section{KARGER}

(c) 2020 S. Karger AG, Basel

karger@karger.com

www.karger.com/pps attain levels of performance beyond that previously attained by "natural" athletes [9]. Consequently, AAS use spread rapidly through the elite athletic world from the 1950s through the 1970s, especially in sports requiring muscle strength, such as field events, weightlifting, and bodybuilding. However, it was not until the 1980s that AAS use began to spill out of the elite athletic world and into the general population. Nowadays, most AAS users are not competitive athletes, but simply men using these drugs primarily for personal appearance $[10,11]$. About $98 \%$ of AAS users are male [12], in part because women rarely desire to be extremely muscular, and are also vulnerable to the androgenic effects of these drugs, such as beard growth, deepening of the voice, and masculinization of secondary sexual characteristics [13]. Consequently, the discussion below is focused on male AAS users.

AAS users frequently use several AAS simultaneously (a practice called "stacking"), often combining both injectable AAS and orally active AAS [8]. For example, a typical stack might include injected testosterone cypionate $400 \mathrm{mg}$ per week plus injected nandrolone decanoate $400 \mathrm{mg}$ per week plus oral methenolone $50 \mathrm{mg}$ per day. Users may also add other appearance- performance-enhancing drugs to the stack (e.g., human growth hormone, clenbuterol, insulin, etc.), as well as drugs to counteract the side effects of AAS, such as anti-estrogens to prevent 
gynecomastia. Discussion of these other classes of drugs can be found elsewhere $[8,14-16]$. Although AAS and these other drugs are illegal without a prescription in most developed Western countries, the drugs are readily available through local underground drug dealers and through numerous Internet sites. In addition, many "nutritional supplements," purchased over the counter or online [17], may contain surreptitious AAS or other ingredients of uncertain efficacy and toxicity [18].

In the 21st century, AAS use has continued to spread widely among men around the world, especially in Nordic countries, the United States, British Commonwealth countries, and Brazil, with many other Western countries following not far behind. AAS use remains rare in east Asia, however, apparently because the Confucian and related traditions in these societies place little value on musculature as a measure of masculinity $[19,20]$, whereas in the West, muscularity has been celebrated since ancient times, with a particular emphasis in the last several decades $[21,22]$. At present, some tens of millions of men worldwide have used AAS, and thus AAS use arguably represents the youngest of the world's major substance use disorders.

Because AAS use is so new, science has only begun to appreciate the potential adverse effects of these substances. Other drugs, such as alcohol, cannabis, and opioids, have been used for thousands of years, and many decades of research have now evaluated the effects of these substances. By contrast, most of the world's older AAS users, those who first tried these drugs as youths in the 1980s or 1990 s, are only now reaching middle age. Consequently, it is only in the last decade or two that it has become feasible to study the long-term effects of AAS [23]. For further discussion of the current state of knowledge, we refer the reader to our earlier comprehensive review [8]. Below, we briefly summarize this literature, with emphasis on effects most likely to be encountered by mental health clinicians.

\section{Medical Effects}

\section{Cardiac Effects}

The best-documented medical hazards of long-term AAS exposure involve the cardiovascular system. This is perhaps not surprising, since AAS affect muscles, and the heart is not only the strongest muscle in the body, but also the only muscle that never rests. Multiple studies have now shown that AAS use can lead to a cardiomyopathy, with compromised systolic function (e.g., an inadequate left ventricular ejection fraction) and diastolic function (e.g., impaired diastolic tissue velocity) $[24,25]$. Tentative evidence, however, suggests that this cardiomyopathy may partially resolve after AAS are discontinued [24]. Perhaps more serious, however, is the association between long-term AAS exposure and atherosclerotic disease, which appears largely attributable to dyslipidemia caused by AAS $[24,26]$. Multiple case reports and small case series have now documented myocardial infarctions and cerebrovascular accidents in young AAS users, and it seems likely that these events will become increasingly common as this population ages $[8,27]$.

\section{Hypogonadism}

Another ominous finding is that AAS users may develop prolonged hypogonadism after discontinuing these drugs [28-30]. In males, testosterone and other AAS all suppress natural production of testosterone and of spermatozoa via feedback inhibition. Thus, when a user discontinues AAS, especially if he has been using AAS for a prolonged period, his own testosterone level will often fall well below the lower limit of normal. This AAS withdrawal hypogonadism may persist for months, and recent evidence suggests that in some cases it may never become fully reversible. As a result, users may suffer prolonged intervals of decreased or absent libido, erectile dysfunction, infertility, and in some instances, major depressive disorder (discussed below). Faced with these effects, users may often resume taking AAS to self-treat the withdrawal symptoms and may ultimately develop an AAS dependence syndrome where they continue to use these drugs without interruption for years of time.

\section{Other Organ Systems}

Long-term AAS exposure may affect other organ systems, although in many cases our understanding of these effects remains limited. AAS may cause hepatotoxicity (although this is uncommon), nephrotoxicity, and possibly neurotoxicity, perhaps with a potential for causing early-onset dementia [31]. AAS users are also at a greater risk for some orthopedic problems, especially ruptured tendons, which can arise when the muscle grows too strong for its attached tendon. Lesser problems include truncal acne, gynecomastia caused by the aromatization of AAS into estrogenic compounds, and hair loss. Use of injections may lead to sepsis or to transmission of viral pathogens, although needle-sharing is rare among AAS users [10]. The reader is referred to recent reviews for more background on these issues $[8,32,33]$.
Kanayama/Hudson/Pope, Jr. 


\section{Psychiatric Effects}

Another category of AAS effects are the psychiatric effects. Among these are: (1) major mood disorders, which may be associated with aggression, violence, and sometimes criminal behavior; (2) muscle dysmorphia, which may be both a cause and an effect of AAS use; and (3) AAS dependence syndromes.

\section{Major Mood Disorders}

Starting in the 1980s, case reports and field studies began to appear, suggesting that AAS might cause some individuals to develop manic or hypomanic syndromes during AAS exposure and depressive symptoms, sometimes associated with suicidal ideation and, rarely, completed suicide, during AAS withdrawal [8, 34-39]. Manic or hypomanic reactions are idiosyncratic, affecting only a minority of AAS users, but may appear quickly, within days or weeks after AAS use is initiated. These reactions appear somewhat dose-related, occurring more commonly in individuals taking more than $1,000 \mathrm{mg}$ of testosterone equivalent per week (which represents 15-20 times the natural male production of testosterone) $[8,34]$. Depressive episodes typically arise within weeks of starting AAS withdrawal, but are also idiosyncratic, affecting only a minority of users $[8,40]$. Importantly, several reports have described men with little or no history of psychiatric disorders or of criminal behavior prior to AAS use who committed murder or other violent crimes when exposed to AAS $[8,35,39,40-46]$. In most of these reported cases, criminal behavior appeared associated with hypomanic symptoms, such as inflated self-esteem or grandiosity, hyperactivity, and involvement in other types of activities with a high potential for painful consequences.

Despite the evidence from the observational studies above, questions remained as to whether the psychological effects observed might be attributable to factors other than AAS themselves - such as underlying personality factors, social effects from the AAS-using subculture, or expectational effects. To address these questions, several placebo-controlled double-blind studies have administered supraphysiologic doses of AAS to volunteers. There have now been four such studies using doses of at least $500 \mathrm{mg}$ per week of testosterone or equivalent AAS [4751]. Of the 109 men who received AAS at $500 \mathrm{mg}$ per week or greater under blinded conditions in these four studies, there were $5(4.6 \%)$ who displayed hypomanic or manic syndromes on AAS, as compared to no such cases on placebo. In one such study [49], a participant with no prior psychiatric history became so aggressive during blinded

Anabolic-Androgenic Steroid Use and

Body Image in Men methyltestosterone administration that he requested to be placed in a seclusion room. In another study [48], a previously asymptomatic man became so aggressive during blinded testosterone administration that he frightened people at his workplace and needed to be withdrawn from the study for safety. In the course of this latter study, the investigators administered the Cherek Point Subtraction Aggression Paradigm, a protocol designed to elicit aggressive responses, to a subgroup of the study participants [52]. These participants displayed strikingly and significantly higher levels of aggression when they were receiving injections of testosterone as compared to placebo under double-blind conditions. In summary, therefore, it is now generally agreed that these AAS effects cannot be explained purely by environmental factors and likely have a biological basis that has yet to be fully elucidated.

\section{Muscle Dysmorphia}

Muscle dysmorphia is a form of body dysmorphic disorder in which an individual becomes concerned that he is not sufficiently muscular. Although they may in fact be very muscular, individuals with muscle dysmorphia may constantly inspect their body size in the mirror, avoid situations in which their bodies might be seen in public for fear that they would look "too small," compulsively lift weights to gain muscle, engage in rigorous high-protein low-fat diets, and frequently go on to use AAS. Although body dysmorphic disorder was recognized as early as the 19th century [53], the subtype of muscle dysmorphia was first described only about 20 years ago $[54,55]$. In the last two decades, muscle dysmorphia has now become the subject of a growing literature, and has now been included in the fifth edition of the American Psychiatric Association's Diagnostic and Statistical Manual of Mental Disorders (DSM-5) as a specific identified subtype of body dysmorphic disorder $[56,57]$. The prevalence of the condition remains uncertain, but it is likely more common than generally believed, since victims rarely disclose their preoccupations to outsiders.

Not surprisingly, AAS use appears widespread among individuals with muscle dysmorphia $[58,59]$. For example, in one study comparing 24 male weightlifters with muscle dysmorphia versus 30 normal comparison weightlifters, $46 \%$ of the men with muscle dysmorphia reported use of AAS as compared to only $7 \%$ of the comparison men [60]. Another study compared 28 bodybuilders to 30 men with eating disorders and 30 comparison men [61]. Although the bodybuilders had not been selected for the presence of muscle dysmorphia, they showed levels of 
body dissatisfaction, comparable to the men with eating disorders and significantly greater than the comparison men; $93 \%$ of the bodybuilders, but none of the men in the other groups, admitted to use of AAS.

Paradoxically, however, when individuals with muscle dysmorphia use AAS and gain substantial amounts of muscle, they often experience little relief from their condition, and may instead become even more preoccupied with their perceived deficits in muscularity. This phenomenon may be partially attributable to mingling with other AAS users in the underground AAS subculture, where there is much discussion of body image and where users may potentiate each other's preoccupations. Unfortunately, individuals with muscle dysmorphia rarely seek psychiatric treatment, and we are not aware of any formal studies of therapeutic interventions for this specific form of body dysmorphic disorder, although serotonin reuptake inhibitors and cognitive behavioral therapy have been shown effective for other forms of body dysmorphic disorder $[62,63]$.

\section{AAS Dependence}

Although AAS are not addictive in the classical sense, a surprisingly high percentage of AAS users develop an AAS dependence syndrome. AAS dependence shares many features with dependence on classical drugs of abuse (e.g., tolerance, withdrawal, large amounts of time devoted to obtaining and using the drug, continued use despite adverse effects), but differ somewhat in that AAS do not deliver an immediate "reward" of intoxication in the manner of most classical drugs. For further discussion of AAS dependence, we refer the reader to our earlier review [64] and to a paper proposing criteria for diagnosing this syndrome [65]. Technically, in the terminology of DSM-5 [56], this syndrome would simply be labeled as an "AAS use disorder" of moderate or greater severity, but the term "AAS dependence" has been generally used in the literature. One analysis, examining pooled data from 10 studies worldwide that had assessed the prevalence of AAS dependence in various populations of users, found that $33 \%$ of users had experienced a dependence syndrome [12]. This high prevalence of dependence appears to arise via at least three separate pathways. First is the "body image pathway": men with muscle dysmorphia will often gravitate to AAS use, as just discussed, and then become reluctant to stop using AAS because they develop anxiety if they lose even a small amount of muscle mass [66]. Second is a "neuroendocrine pathway": as also mentioned above, men will frequently become hypogonadal after stopping a course of AAS and will then be tempted to resume using AAS after a short period in order to self- treat loss of libido, impaired erectile function, and possible depression [67]. Third, recent research has shown a "hedonic pathway," which has been well demonstrated in rodent models. For example, male hamsters will self-inject testosterone to the point of death, suggesting that they are experiencing a hedonic effect from the drug. This self-administration occurs even when the testosterone is administered directly into the cerebral ventricles, suggesting that dependence in hamsters cannot be attributed to a peripheral action of the drug [68]. Human AAS users do not uniformly describe a hedonic effect from AAS, but many describe feelings of greater self-confidence, or even a sense of being "invincible" when using the drugs - and these rewarding feelings may well contribute to the evolution of a dependence syndrome [66].

\section{Clinical Evaluation}

As increasing numbers of men use AAS, and as more of them move into middle age, mental health professionals will likely encounter more patients with AAS-related problems. However, AAS users are often skeptical of clinicians and reluctant to disclose their AAS use [69]. Thus, clinicians must be alert for signs of surreptitious AAS use, particularly in men who report weightlifting and display unusual muscularity. Other physical signs (e.g., truncal acne, gynecomastia, or prominence striae above the pectoralis muscles) and laboratory measures (e.g., abnormally high hematocrit, low HDL cholesterol, or high levels of testosterone along with suppressed luteinizing and follicle-stimulating hormones) may further increase a treater's index of suspicion (Table 1). Note that if an AAS user is taking other types of AAS but not testosterone, his testosterone level will be abnormally low, but LH and FSH will also be low. AAS users may also show elevated levels of alanine aminotransferase, aspartate aminotransferase, and creatine kinase, but these are nonspecific findings, since all of these enzymes are present in muscle, and may be substantially elevated from the trauma of weightlifting alone, even in the absence of AAS. In any case where the clinician has suspicions, a gentle and nonjudgmental inquiry may help to uncover an AAS history [70]. Upon obtaining such a history, clinicians should assess lifetime doses and durations of AAS use with particular attention to the possibility of AAS dependence. They should also inquire about comorbid conditions, including use of other appearance- and performance-enhancing drugs, classical substance use disorders (which are common among AAS users), muscle dysmorphia and other forms of body dysmorphic disorder, and
68

Psychother Psychosom 2020;89:65-73 DOI: $10.1159 / 000505978$
Kanayama/Hudson/Pope, Jr. 
Table 1. Laboratory abnormalities in anabolic-androgenic steroid users

\begin{tabular}{|c|c|}
\hline \multicolumn{2}{|l|}{ Blood chemistries } \\
\hline Muscle enzymes & Increased CK, ALT, AST, and LDH \\
\hline Liver function tests & $\begin{array}{l}\text { Increased ALT, AST, LDH, GGT and total bilirubin (caution: increased ALT, AST, and } \\
\text { LDH are often muscular in origin and do not indicate liver disease) }\end{array}$ \\
\hline \multirow[t]{2}{*}{ Lipids } & Decreased HDL-C, increased LDL-C \\
\hline & Increase or no change in total cholesterol and triglycerides \\
\hline \multirow[t]{3}{*}{ Hormonal levels } & Increased testosterone and estradiol (with use of testosterone esters) \\
\hline & Decreased testosterone (in individuals using other AAS but not testosterone) \\
\hline & Decreased FSH and LH \\
\hline Hematology & Increased RBC count, hemoglobin, and hematocrit \\
\hline \multirow[t]{2}{*}{ Urine testing } & Positive for AAS in individuals currently or recently on AAS \\
\hline & May be positive for other drugs of abuse as well \\
\hline Electrocardiogram & Left ventricular hypertrophy (seen in intensive weight trainers also) \\
\hline \multicolumn{2}{|l|}{ Echocardiogram } \\
\hline Systolic function & Decreased left ventricular ejection fraction \\
\hline Diastolic function & Decreased left ventricular relaxation velocity \\
\hline Semen analysis & Decreased sperm count and motility, abnormal morphology \\
\hline \multicolumn{2}{|c|}{$\begin{array}{l}\text { AAS, anabolic-androgenic steroids; CK, creatine kinase; ALT, alanine aminotransferase; AST, aspartate amino- } \\
\text { transferase; LDH, lactate dehydrogenase; GGT, gamma-glutamyl transferase; HDL-C, high-density lipoprotein cho- } \\
\text { lesterol; LDL-C, low-density lipoprotein cholesterol; LH, luteinizing hormone; FSH, follicle stimulating hormone; } \\
\text { RBC, red blood cell. } \\
\text { Reprinted with permission from the Textbook of Substance Abuse Treatment, Fifth Edition (copyright (C) 2015). } \\
\text { American Psychiatric Association. All Rights Reserved. }\end{array}$} \\
\hline
\end{tabular}

major mood disorders - especially hypomanic symptoms during AAS exposure and depressive symptoms during AAS withdrawal. A more detailed discussion of the suggested history, physical examination, and laboratory testing of AAS users can be found elsewhere [71].

\section{Treatment}

Unfortunately, because AAS use and dependence are relatively new, there is little research on the treatment of this condition. Moreover, substance use treatment facilities are often poorly informed about AAS use, and standard paradigms for treating classical substance use disorders may not be well suited for AAS users. Despite this paucity of data, we can offer some recommendations, summarized in Figure 1, which portrays the three pathways to AAS dependence enumerated above. As noted in the figure, the anabolic and androgenic effects of AAS result from entry of the AAS molecules into the nuclei of cells, where these molecules bind to intra-nuclear androgen receptors, which in turn generates messenger RNA that ultimately mediates these effects throughout the body. By contrast, the hedonic effects of AAS are believed to result from binding of AAS molecules to cell membranes, particularly in the nucleus accumbens. To effectively manage AAS dependence, it seems important to address all three pathways simultaneously when initiating treatment in order to maximize efficacy.

\section{The Body Image Pathway}

AAS users, even if they do not suffer from outright muscle dysmorphia, very often experience at least some pathology related to body image. Persuading an AAS user to stop using the drugs and potentially lose muscle is often as difficult as persuading patients with anorexia nervosa that they need to gain weight. Thus, clinicians must be sympathetic and sensitive to the unique concerns of these individuals. As noted above, there are little formal data on the treatment of muscle dysmorphia, although it appears reasonable to expect that this disorder may respond to treatments previously found effective for other forms of body dysmorphic disorder, including cognitive behavioral approaches that are specifically tailored to body dysmorphic disorder [72] and treatment with selective serotonin reuptake inhibitors [73]. 


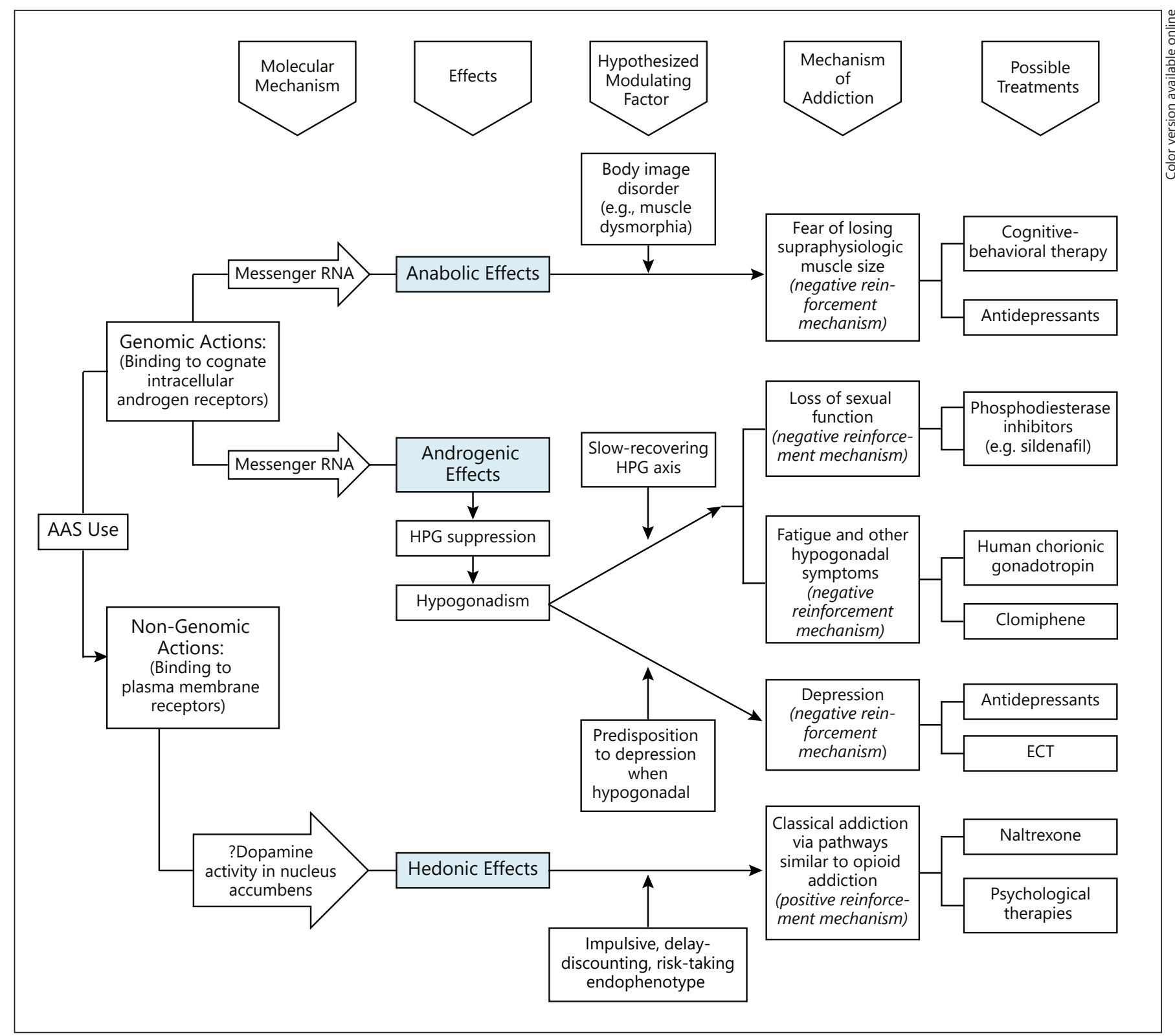

Fig. 1. A diagram of three pathways that may lead to anabolicandrogenic steroid dependence, together with possible therapeutic strategies to address each pathway. ECT, electroconvulsive therapy; HPG, hypothalamic-pituitary-gonadal; RNA, ribonucleic acid. Note that the term "anabolic effects" in the figure refers to the muscle-building effects of AAS, and "androgenic effects" refers to

\section{The Neuroendocrine Pathway}

Dysphoria associated with AAS withdrawal hypogonadism may potentiate the urge to resume taking AAS, and thus hypogonadism deserves aggressive treatment. If hypogonadism is pronounced and prolonged, as may be the case during withdrawal from long-term AAS use [28- the masculinizing effects of these hormones. Note also that the types of antidepressants effective for body dysmorphic disorder are primarily serotonin reuptake inhibitors, whereas antidepressants from a wider range of chemical families may be effective for treating depression associated with hypogonadism. Reprinted from Kanayama et al. [66], with permission from Elsevier.

30], it is desirable to engage the services of an endocrinologist familiar with AAS withdrawal, although in our experience individuals with substantial expertise in this area are often hard to find. An endocrinologist might initially maintain the patient on a temporary modest dose of testosterone, while introducing human chorionic gonad- 
otropin to restore pituitary production of luteinizing and follicle-stimulating hormones, and while also initiating clomiphene, often in conjunction with an aromatase inhibitor such as tamoxifen, in order to stimulate gonadotropin release from the pituitary [74]. Even with expert management of these endocrine parameters, treatment of hypogonadism may be prolonged and incomplete.

Meanwhile, psychiatric intervention may be necessary if the patient develops depression in association with AAS withdrawal. In studies of medically induced hypogonadism, it has been found that a majority of patients do not develop depression, but a minority, perhaps $10-20 \%$, may develop serious depressive symptoms [75]. One small case series has described successful use of fluoxetine to treat such depression [76], and another individual case report described success with electroconvulsive therapy [77], but systematic studies are lacking. Thus, pending more definitive research, clinicians should approach AAS withdrawal depression in the same manner as an ordinary episode of major depressive illness. As noted above, treatment of the muscle dysmorphia form of body dysmorphic disorder, if present, with serotonin reuptake inhibitors may be efficacious for both body dysmorphic disorder and depressive symptoms [62].

\section{The Hedonic Pathway}

As mentioned above, male hamsters will self-inject testosterone to the point of death, but interestingly this behavior is blocked by the opioid antagonist naltrexone [78]. Indeed, several other reports have suggested parallels between the hedonic effects of opioids and those of AAS [8]. Thus, treatments found effective for opioid dependence might plausibly be helpful for AAS users. Such treatments might include motivational therapies to encourage commitment to treatment, contingency management, behavioral couple's therapy, and supportive-expressive therapy. Couple's treatment might be particu- larly promising with AAS users, since partners of AAS users are often eager for the AAS user to discontinue the drugs. We are not aware of any reports of naltrexone in the treatment of AAS dependence, although on theoretical grounds this drug might theoretically be effective.

In summary, then, at the present limited state of knowledge, much of the treatment of AAS users must be based on the clinician's assessment of each individual case. Now that AAS use has risen to become one of the world's major substance use disorders, it will become increasingly important for mental health professionals to stay abreast of evolving knowledge in this area.

\section{Acknowledgement}

The authors wish to acknowledge Dr. Katharine Phillips for her critical review and commentary on an initial draft of the manuscript.

\section{Disclosure Statement}

Dr. Pope has testified twice in the last 3 years in legal cases involving anabolic-androgenic steroids. Dr. Hudson has received support from Sunovion, and has received consulting fees from Idorsia, Shire, and Sunovion. Dr. Kanayama reports no conflicts of interest.

\section{Funding Sources}

No funding was received for the preparation of this editorial.

\section{Author Contributions}

All authors contributed to the conception, drafting, and final revision of the manuscript.

\section{References}

1 Snaith P. Body image disorders. Psychother Psychosom. 1992;58(3-4):119-24.

2 Guaraldi GP, Orlandi E, Boselli P, Tartoni PL. Body size perception and dissatisfaction in female subjects of different ages. Psychother Psychosom. 1995;64(3-4):149-55.

3 Jaeger B, Ruggiero GM, Edlund B, GomezPerretta C, Lang F, Mohammadkhani P, et al. Body dissatisfaction and its interrelations with other risk factors for bulimia nervosa in 12 countries. Psychother Psychosom. 2002 Jan-Feb;71(1):54-61.
4 McCabe MP, Ricciardelli LA. Body image dissatisfaction among males across the lifespan: a review of past literature. J Psychosom Res. 2004 Jun;56(6):675-85.

5 Pope H, Phillips K, Olivardia R. The Adonis complex: The secret crisis of male body obsession. New York: Simon \& Schuster; 2000.

6 Kanayama G, Pope HG Jr, Hudson JI. "Body image" drugs: a growing psychosomatic problem. Psychother Psychosom. 2001 Mar-Apr; 70(2):61-5.
7 Pope HG Jr, Khalsa JH, Bhasin S. Body image disorders and abuse of anabolic-androgenic steroids among men. JAMA. 2017 Jan;317(1):23-4.

8 Pope HG Jr, Wood RI, Rogol A, Nyberg F, Bowers L, Bhasin S. Adverse health consequences of performance-enhancing drugs: an Endocrine Society scientific statement. Endocr Rev. 2014 Jun;35(3):341-75.

9 Kanayama G, Pope HG. History and epidemiology of anabolic androgens in athletes and non-athletes. Mol Cell Endocrinol. 2018 Mar; 464:4-13. 
10 Ip EJ, Barnett MJ, Tenerowicz MJ, Perry PJ. The Anabolic 500 survey: characteristics of male users versus nonusers of anabolic-androgenic steroids for strength training. Pharmacotherapy. 2011 Aug;31(8):757-66.

11 Parkinson AB, Evans NA. Anabolic androgenic steroids: a survey of 500 users. Med Sci Sports Exerc. 2006 Apr;38(4):644-51.

12 Pope HG Jr, Kanayama G, Athey A, Ryan E, Hudson JI, Baggish A. The lifetime prevalence of anabolic-androgenic steroid use and dependence in Americans: current best estimates. Am J Addict. 2014 Jul-Aug;23(4):3717.

13 Gruber AJ, Pope HG Jr. Psychiatric and medical effects of anabolic-androgenic steroid use in women. Psychother Psychosom. 2000; 69(1):19-26.

14 Brennan BP, Kanayama G, Hudson JI, Pope HG Jr. Human growth hormone abuse in male weightlifters. Am J Addict. 2011 JanFeb;20(1):9-13.

15 Ip EJ, Barnett MJ, Tenerowicz MJ, Perry PJ. Weightlifting's risky new trend: a case series of 41 insulin users. Curr Sports Med Rep. 2012 Jul-Aug;11(4):176-9.

16 Prather ID, Brown DE, North P, Wilson JR. Clenbuterol: a substitute for anabolic steroids? Med Sci Sports Exerc. 1995 Aug;27(8): 1118-21.

17 Kanayama G, Gruber AJ, Pope HG Jr, Borowiecki JJ, Hudson JI. Over-the-counter drug use in gymnasiums: an underrecognized substance abuse problem? Psychother Psychosom. 2001 May-Jun;70(3):137-40.

18 Geyer H, Parr MK, Koehler K, Mareck U, Schänzer W, Thevis M. Nutritional supplements cross-contaminated and faked with doping substances. J Mass Spectrom. 2008 Jul; 43(7):892-902.

19 Kanayama G, Hudson JI, Pope HG Jr. Culture, psychosomatics and substance abuse: the example of body image drugs. Psychother Psychosom. 2012;81(2):73-8.

20 Yang CF, Gray P, Pope HG Jr. Male body image in Taiwan versus the West: yanggang Zhiqi meets the Adonis complex. Am J Psychiatry. 2005 Feb;162(2):263-9.

21 Pope HG Jr, Olivardia R, Borowiecki JJ 3rd, Cohane GH. The growing commercial value of the male body: a longitudinal survey of advertising in women's magazines. Psychother Psychosom. 2001 Jul-Aug;70(4):189-92.

22 Pope HG Jr, Olivardia R, Gruber A, Borowiecki J. Evolving ideals of male body image as seen through action toys. Int J Eat Disord. 1999 Jul;26(1):65-72.

23 Kanayama G, Hudson JI, Pope HG Jr. Longterm psychiatric and medical consequences of anabolic-androgenic steroid abuse: a looming public health concern? Drug Alcohol Depend. 2008 Nov; $98(1-2): 1-12$.

24 Baggish AL, Weiner RB, Kanayama G, Hudson JI, Lu MT, Hoffmann U, et al. Cardiovascular toxicity of illicit anabolic-androgenic steroid use. Circulation. 2017 May;135(21): 1991-2002.
25 D'Andrea A, Caso P, Salerno G, Scarafile R, De Corato G, Mita C, et al. Left ventricular early myocardial dysfunction after chronic misuse of anabolic androgenic steroids: a Doppler myocardial and strain imaging analysis. Br J Sports Med. 2007 Mar;41(3):149-55.

26 Santora LJ, Marin J, Vangrow J, Minegar C, Robinson M, Mora J, et al. Coronary calcification in body builders using anabolic steroids. Prev Cardiol. 2006;9(4):198-201.

27 Pärssinen M, Kujala U, Vartiainen E, Sarna S, Seppälä T. Increased premature mortality of competitive powerlifters suspected to have used anabolic agents. Int J Sports Med. 2000 Apr;21(3):225-7.

28 Coward RM, Rajanahally S, Kovac JR, Smith RP, Pastuszak AW, Lipshultz LI. Anabolic steroid induced hypogonadism in young men. J Urol. 2013 Dec;190(6):2200-5.

29 Kanayama G, Hudson JI, DeLuca J, Isaacs S, Baggish A, Weiner R, et al. Prolonged hypogonadism in males following withdrawal from anabolic-androgenic steroids: an underrecognized problem. Addiction. 2015 May; 110(5):823-31.

30 Rasmussen JJ, Selmer C, Østergren PB, Pedersen KB, Schou M, Gustafsson F, et al. Former abusers of anabolic androgenic steroids exhibit decreased testosterone levels and hypogonadal symptoms years after cessation: a case-control study. PLoS One. 2016 Aug; 11(8):e0161208.

31 Kaufman MJ, Kanayama G, Hudson JI, Pope HG Jr. Supraphysiologic-dose anabolic-androgenic steroid use: A risk factor for dementia? Neurosci Biobehav Rev. 2019 May;100: 180-207.

32 Talih F, Fattal O, Malone D Jr. Anabolic steroid abuse: psychiatric and physical costs. Cleve Clin J Med. 2007 May;74(5):341-4.

33 Vorona E, Nieschlag E. Adverse effects of doping with anabolic androgenic steroids in competitive athletics, recreational sports and bodybuilding. Minerva Endocrinol. 2018 Dec;43(4):476-88.

34 Pope HG Jr, Katz DL. Psychiatric and medical effects of anabolic-androgenic steroid use. A controlled study of 160 athletes. Arch Gen Psychiatry. 1994 May;51(5):375-82.

35 Choi PY, Parrott AC, Cowan D. High-dose anabolic steroids in strength athletes: effects upon hostility and aggression. Hum Psychopharmacol. 1990;5(4):349-56.

36 Malone DA Jr, Dimeff RJ, Lombardo JA, Sample RH. Psychiatric effects and psychoactive substance use in anabolic-androgenic steroid users. Clin J Sport Med. 1995;5(1):25-31.

37 Yates WR, Perry PJ, Andersen KH. Illicit anabolic steroid use: a controlled personality study. Acta Psychiatr Scand. 1990 Jun;81(6): 548-50.

38 Pope HG, Katz DL. Psychiatric effects of exogenous anabolic-androgenic steroids. In: Wolkowitz OM, Rothschild AJ, editors. Psychoneuroendocrinology: The scientific basis of clinical practice. Washington (DC): American Psychiatric Press; 2003. pp. 331-58.
39 Hall RC, Hall RC, Chapman MJ. Psychiatric complications of anabolic steroid abuse. Psychosomatics. 2005 Jul-Aug;46(4):285-90.

40 Rubinow DR, Schmidt PJ. Androgens, brain, and behavior. Am J Psychiatry. 1996 Aug; 153(8):974-84

41 Conacher GN, Workman DG. Violent crime possibly associated with anabolic steroid use. Am J Psychiatry. 1989 May;146(5):679.

42 Pope HG Jr, Katz DL. Homicide and near-homicide by anabolic steroid users. J Clin Psychiatry. 1990 Jan;51(1):28-31.

43 Pope HG Jr, Kouri EM, Powell KF, Campbell C, Katz DL. Anabolic-androgenic steroid use among 133 prisoners. Compr Psychiatry. 1996 Sep-Oct;37(5):322-7.

44 Dalby JT. Brief anabolic steroid use and sustained behavioral reaction. Am J Psychiatry. 1992 Feb;149(2):271-2.

45 Schulte HM, Hall MJ, Boyer M. Domestic violence associated with anabolic steroid abuse. Am J Psychiatry. 1993 Feb;150(2):348.

46 Stanley A, Ward M. Anabolic steroids-the drugs that give and take away manhood. A case with an unusual physical sign. Med Sci Law. 1994 Jan;34(1):82-3.

47 Bhasin S, Storer TW, Berman N, Callegari C, Clevenger B, Phillips J, et al. The effects of supraphysiologic doses of testosterone on muscle size and strength in normal men. N Engl J Med. 1996 Jul;335(1):1-7.

48 Pope HG Jr, Kouri EM, Hudson JI. Effects of supraphysiologic doses of testosterone on mood and aggression in normal men: a randomized controlled trial. Arch Gen Psychiatry. 2000 Feb;57(2):133-40.

49 Su TP, Pagliaro M, Schmidt PJ, Pickar D, Wolkowitz O, Rubinow DR. Neuropsychiatric effects of anabolic steroids in male normal volunteers. JAMA. 1993 Jun;269(21):2760-4.

50 Tricker R, Casaburi R, Storer TW, Clevenger B, Berman N, Shirazi A, et al. The effects of supraphysiological doses of testosterone on angry behavior in healthy eugonadal men-a clinical research center study. J Clin Endocrinol Metab. 1996 Oct;81(10):3754-8.

51 Yates WR, Perry PJ, MacIndoe J, Holman T, Ellingrod V. Psychosexual effects of three doses of testosterone cycling in normal men. Biol Psychiatry. 1999 Feb;45(3):254-60.

52 Kouri EM, Lukas SE, Pope HG Jr, Oliva PS. Increased aggressive responding in male volunteers following the administration of gradually increasing doses of testosterone cypionate. Drug Alcohol Depend. 1995 Nov;40(1):73-9.

53 Fava GA. Morselli's legacy: dysmorphophobia. Psychother Psychosom. 1992;58(3-4): $117-8$.

54 Pope HG Jr, Gruber AJ, Choi P, Olivardia R, Phillips KA. Muscle dysmorphia. An underrecognized form of body dysmorphic disorder. Psychosomatics. 1997 Nov-Dec;38(6): $548-57$.

55 Pope HG Jr, Katz DL, Hudson JI. Anorexia nervosa and "reverse anorexia" among 108 male bodybuilders. Compr Psychiatry. 1993 Nov-Dec;34(6):406-9. 
56 American Psychiatric Association. Diagnostic and Statistical Manual of Mental Disorders. 5th ed. Washington: American Psychiatric Association; 2013.

57 Phillips KA, Wilhelm S, Koran LM, Didie ER, Fallon BA, Feusner J, et al. Body dysmorphic disorder: some key issues for DSM-V. Depress Anxiety. 2010 Jun;27(6):573-91.

58 McCreary DR, Hildebrandt TB, Heinberg LJ, Boroughs M, Thompson JK. A review of body image influences on men's fitness goals and supplement use. Am J Men Health. 2007 Dec; 1(4):307-16.

59 Rohman L. The relationship between anabolic androgenic steroids and muscle dysmorphia: a review. Eat Disord. 2009 May-Jun; 17(3):187-99.

60 Olivardia R, Pope HG Jr, Hudson JI. Muscle dysmorphia in male weightlifters: a case-control study. Am J Psychiatry. 2000 Aug;157(8): 1291-6.

61 Mangweth B, Pope HG Jr, Kemmler G, Ebenbichler C, Hausmann A, De Col C, et al. Body image and psychopathology in male bodybuilders. Psychother Psychosom. 2001 JanFeb;70(1):38-43.

62 Phillips KA. Pharmacotherapy and other somatic treatments for body dysmorphic disorder. In: Phillips KA, editor. Body dysmorphic disorder: advances in research and clinical practice. New York: Oxford University press; 2017. pp. 333-55.

63 Rasmussen J, Gomez A, Wilhelm S. Cognitive-behavioral therapy for body dysmorphic disorder. In: Phillips KA, editor. Body dysmorphic disorder: advances in research and clinical practice. New York: Oxford University press; 2017. pp. 357-77.

64 Kanayama G, Brower KJ, Wood RI, Hudson JI, Pope HG Jr. Anabolic-androgenic steroid dependence: an emerging disorder. Addiction. 2009 Dec;104(12):1966-78.

65 Kanayama G, Brower KJ, Wood RI, Hudson JI, Pope HG Jr. Issues for DSM-V: clarifying the diagnostic criteria for anabolic-androgenic steroid dependence. Am J Psychiatry. 2009 Jun;166(6):642-5.

66 Kanayama G, Brower KJ, Wood RI, Hudson JI, Pope HG Jr. Treatment of anabolic-androgenic steroid dependence: emerging evidence and its implications. Drug Alcohol Depend. 2010 Jun;109(1-3):6-13

67 Kashkin KB, Kleber HD. Hooked on hormones? An anabolic steroid addiction hypothesis. JAMA. 1989 Dec;262(22):3166-70.

68 Wood RI, Johnson LR, Chu L, Schad C, Self DW. Testosterone reinforcement: intravenous and intracerebroventricular self-administration in male rats and hamsters. Psychopharmacology (Berl). 2004 Jan;171(3):298305.

69 Pope HG, Kanayama G, Ionescu-Pioggia M, Hudson JI. Anabolic steroid users' attitudes towards physicians. Addiction. 2004 Sep; 99(9):1189-94.

70 Brower KJ. Anabolic steroid abuse and dependence in clinical practice. Phys Sportsmed. 2009 Dec;37(4):131-40.

71 Pope HG, Kanayama G. Treatment of anabolic-androgenic steroid related disorders. In: Brady K, Levin F, Galanter M, Kleber HD, editors. The American Psychiatric
Press Textbook of Substance Abuse Treatment. 6th ed. Washington (DC): American Psychiatric Association Publishing; [In press]. https://doi.org/10.1007/978-88-4705322-9_28.

72 Veale D, Anson M, Miles S, Pieta M, Costa A, Ellison N. Efficacy of cognitive behaviour therapy versus anxiety management for body dysmorphic disorder: a randomised controlled trial. Psychother Psychosom. 2014; 83(6):341-53.

73 Kelly MM, Phillips KA. Update on body dysmorphic disorder: clinical features, epidemiology, pathogenesis, assessment, and treatment. Psychiatr Ann. 2017;47(11):5528.

74 Tan RS, Scally MC. Anabolic steroid-induced hypogonadism - towards a unified hypothesis of anabolic steroid action. Med Hypotheses. 2009 Jun; 72(6):723-8.

75 Schmidt PJ, Berlin KL, Danaceau MA, Neeren A, Haq NA, Roca CA, et al. The effects of pharmacologically induced hypogonadism on mood in healthy men. Arch Gen Psychiatry. 2004 Oct;61(10):997-1004.

76 Malone DA Jr, Dimeff RJ. The use of fluoxetine in depression associated with anabolic steroid withdrawal: a case series. J Clin Psychiatry. 1992 Apr;53(4):130-2.

77 Allnutt S, Chaimowitz G. Anabolic steroid withdrawal depression: a case report. Can J Psychiatry. 1994 Jun;39(5):317-8.

78 Peters KD, Wood RI. Androgen dependence in hamsters: overdose, tolerance, and potential opioidergic mechanisms. Neuroscience. 2005;130(4):971-81. 